\title{
PENERAPAN METODE SUGESTOPEDIA UNTUK MENINGKATKAN KEMAMPUAN MENULIS PUISI SISWA KELAS V SEKOLAH DASAR
}

\section{APPLICATION OF SUGESTOPEDIA METHODS TO IMPROVE THE WRITING POETRY ABILITY OF VOCATIONAL SCHOOL OF ELEMENTARY SCHOOL}

\author{
SW Anggraeni ${ }^{1}$ dan Y Alpian ${ }^{1}$ \\ 1Program Studi Pendidikan Guru Sekolah Dasar, Fakultas Keguruan dan Ilmu Pendidikan \\ Universitas Buana Perjuangan Karawang, Jl. HS Ronggowaluyo, Telukjambe Timur Karawang Indonesia \\ a Korespondensi: Sri Wulan Anggraeni, Email: wulan.anggraeni@ubpkarawang.ac.id
}

(Diterima: 28-08-2018; Ditelaah: 07-09-2018; Disetujui: 17-09-2018)

\begin{abstract}
This study is aimed to know students' ability in increasing their poem writing at SDN muktiwari 02 by using method of sugestopedia. Research methodology used is classroom action research. The study is done in three of any cycles through research repeated, consisting of four stage, the plan, take action, observing, and reflection. This research result indicates that learning wrote poems by applying a method of sugestopedia can improve the ability of students writing poetry. Proven with the activity and study results wrote poems students on initial conditions pre cycle the average value of 51,88. After conducted the act of by applying method sugestopedia increased where the cycle I the average value of 62.5 , cycle II the average value of 68,95 , and in cycle III the mean value of the 75,2 . Hence, learning by applying method sugestopedia can improve the ability wrote poems. Implication this research shown to educator, researchers, and institution or intansi related especially the school that can more vulnerable to student needs and creative educator in learning especially learning the indonesian language especially learning wrote poems.
\end{abstract}

Keywords: method sugestopedia, writing ability poetry.

\begin{abstract}
ABSTRAK
Penelitian ini bertujuan untuk mengetahui peningkatan kemampuan menulis puisi siswa SDN Muktiwari 02 melalui penerapan metode sugestopedia. Metode penelitian yang digunakan adalah penelitian tindakan kelas. Penelitian ini dilakukan sebanyak tiga siklus yang setiap siklusnya melalui proses pengkajian yang terdiri dari empat tahap, yaitu merencanakan, melakukan tindakan, mengamati, dan melakukan refleksi. Hasil penelitian ini menunjukkan bahwa pembelajaran menulis puisi dengan menerapkan metode sugestopedia dapat meningkatkan kemampuan menulis puisi siswa. Terbukti dengan aktivitas dan hasil belajar menulis puisi siswa pada kondisi awal pra siklus dengan nilai rata-rata 51,88. Setelah dilakukan tindakan dengan menerapkan metode sugestopedia mengalami peningkatan yaitu pada siklus I dengan nilai rata-rata 62,5,siklus II dengan nilai rata-rata 68,95, dan pada siklus III nilai rata-rata 75,2 . Oleh karena itu, pembelajaran dengan menerapkan metode sugestopedia dapat meningkatkan kemampuan menulis puisi. Implikasi penelitian ini ditujukan kepada pendidik, peneliti, dan lembaga atau intansi yang terkait khususnya pihak sekolah agar dapat lebih peka terhadap kebutuhan siswa dan meningkatkan kreativitas pendidik dalam proses pembelajaran terutama pembelajaran bahasa Indonesia khusunya pembelajaran menulis puisi.
\end{abstract}

Kata kunci: kemampuan menulis puisi, metode sugestopedia. 
Anggraeni, S. W, \& Alpian, Y. (2018). Penerapan Metode Sugestopedia untuk Meningkatkan Kemampuan Menulis Puisi Siswa Kelas V Sekolah Dasar. Didaktika Tauhidi: Jurnal Pendidikan Guru Sekolah Dasar, 5(2): 106-122.

\section{PENDAHULUAN}

Pembelajaran bahasa Indonesia di Sekolah Dasar (SD) merupakan bagian penting dalam kerangka pengembangan pendidikan nasional yang bertujuan untuk menciptakan manusia yang memiliki kompetensi berbahasa yang optimal. Menulis puisi merupakan salah satu kemampuan berbahasa Indonesia yang diajarkan di Sekolah Dasar. Menulis puisi perlu ditanamkan kepada siswa di Sekolah Dasar untuk membantu keterampilan berbahasa, mengasah imajinasi mengembangkan cipta rasa, mencetak siswa menjadi siswa kreatif, tanggap terhadap masalah, menunjang pembentukan watak, meningkatkan kepekaan emosi disekitarnya dan sejumlah manfaat lainya.

Proses pembelajaran yang berlangsung dengan suasana yang menyenangkan, tentunya akan menghasilkan sesuatu yang membanggakan. Apabila seorang guru menyajikan dengan metode pembelajaran yang lain daripada biasanya, siswa yang mengikuti pembelajaran tersebut akan menjadi antusias pada saat proses pembelajaran berlangsung. Dengan demikian, kegiatan menulis bukanlah sesuatu yang harus ditakuti oleh siswa khususnya pada pembelajaran menulis puisi. Metode yang digunakan yaitu dengan menerapkan konsep sugestopedia. Melalui metode sugestopedia siswa dapat berlatih menulis puisi dengan cara mengkondisikan siswa dengan sugesti sehingga siswa dalam keadaan yang nyaman dan larut dalam keadaan yang sesuai dengan disugestikan. Dalam keadaan ini, siswa mudah untuk menemukan kata-kata dalam puisi.
Pembelajaran menulis puisi di SD sesuai dengan Kurikulum 2013 bertujuan meningkatkan kecakapan dalam berbahasa secara tepat dan kreatif, meningkatkan kemampuan berpikir logis dan bernalar, serta meningkatkan kepekaan perasaan dan kemampuan siswa untuk memahami dan menikmati karya sastra. Selain itu, pembelajaran menulis puisi dimaksudkan agar siswa terdidik menjadi manusia yang berkepribadian, sopan, dan beradab, berbudi pekerti yang halus, memiliki rasa kemanusiaan, berkepedulian sosial, memiliki apresiasi budaya dan penyaluran gagasan, berimajinasi, berekspresi secara kreatif baik secara lisan maupuan tertulis. Pembelajaran menulis puisi dimaksudkan untuk meningkatkan kemampuan siswa dalam menikmati, mengalami dan merasakan sesuatu dalam batinnya,serta memahami karya puisi.

Menulis sebagai proses melambangkan bunyi-bunyi ujaran ke dalam bentuk tulisan. Melalui lambang-lambang tersebutlah pembaca dapat memahami yang dikomunikasikan penulis. Menurunkan atau melukiskan lambang- lambang grafik yang menggambarkan suatu symbol yang dapat dipahami oleh seseorang sehingga orang lain dapat membaca serta memahami lambang- lambang grafik tersebut disebut menulis (Tarigan 1982: 22)

Salah satu kegiatan menulis yang diajarkan di SD yaitu menulis puisi. Menulis puisi merupakan pembelajaran sastra yang memang harus diberikan kepada anak mulai dari sekolah dasar, agar mereka terbiasa untuk mengenal dan memahami keindahan para pengarang. Sastra anak berfungsi sebagai memberi banyak informasi tentang 
sesuatu hal, memberi banyak pengetahuan, memberi kreativitas atau keterampilan anak, dan juga memberi didikan moral pada anak. Sedangkan fungsi hiburan sastra anak jelas memberi kenangan, kenikmatan, dan pada diri anak.

Samuel Taylor Colerige (Pradopo 2005:6), mengemukakan bahwa puisi itu kata-kata terindah dalam susunan terindah. Penyair Penyair pemilihan kata-kata yang tepat dan disusun secara baik, misalnya selaras, simetris, antara satu bait dengan bait lain sangat erat hubungannya, dan sebagainya. Ini menunjukkan bahwa menulis puisi perlu keterampilan dalam berbahasa terutama keterampilan dalam memilih kata dan menyusun kata sehingga menghasilkan puisi yang indah.

Menurut Suyuti (Sadikin M, 2010: 23) menyatakan bahwa puisi adalah cara berbahasa yang memperhitungkan aspekaspek bunyi di dalamnya, yang memaparkan pengalaman yang bersifat khayal, dengan rasa emosi dan tingkat pemahaman seorang penyair yang diambil dari kehidupan keseharian dan sosialnya, yang diungkapkan dengan cara tertentu sehingga puisi yang dihasilkan dapat membangkitkan pengalaman bagi pembaca atau pendengarnya. Sejalan dengan Waluyo (1987:22), puisi adalah karya sastra. Semua karya sastra yang bersifat khayal. Bahasa sastra bersifat konotatif karena banyak digunakan makna persamaan dan atau perbandingan serta makna lambang (majas). Dibandingkan dengan bentuk lain, puisi lebih bersifat konotatif. Bahasanya lebih memiliki banyak kemungkinan makna. Hal ini disebabkan terjadinya pengkonsentrasian atau pemadatan segenap kekuatan bahasa di dalam puisi. Hal ini menjelaskan bahwa puisi adalah karya yang isinya berupa ungkapan pengalaman penyair yang diungkapkan dengan metode tertentu seperti penggunaan kata yang konotatif dan di dalamnya memperhatikan aspek-aspek bunyi sehingga menghasilkan bahasa yang indah.

Mulai dari Sekolah dasar anak sudah diajarkan menulis puisi yang merupakan pembelajaran sastra, agar anak mengenal dan memahami keindahan para pengarang. Sastra anak merupakan sebagai pemberi informasi tentang sesuatu hal, memberikan banyak pengetahuan, memberi kesempatan kepada anak untuk mencipta, dan menjadi sarana pembelajaran pendidikan moral bagi anak, selain itu sastra berfungsi sebagai hiburan yang dapat memberikan kesan yang berarti, serta kesenangan pada diri anak.

Kompetensi dasar yang terdapat dalam kurikulum 2013 mengemukakan bahwa menulis kreatif (menulis puisi) itu mempunyai dua tujuan utama. Pertama, siswa memakai bahasa untuk dimengerti dengan benar, mengembangkan, dan mengungkapkan gagasan dan informasi, serta untuk berintegrasi dengan orang lain. Kedua, para siswa juga diharapkan dapat memahami dan berpartisipasi dalam kegiatan menulis kreatif agar mereka dapat menghargai karya artistik, budaya, intelektual, serta menerapkan nilai-nilai luhur untuk meningkatkan kematangan pribadi menuju masyarakat beradab (Depdiknas, 2006: 15)

Puisi yang ditulis secara kreatif oleh siswa dapat bersifat imajinatif, intelektual, dan emosional apabila diolah sedemikian rupa sehingga puisii tesebut tampak jelas, mudah ditangkap, dan menyentuh perasaan. Hal tersebut menandakan bahwa kegiatan menulis puisi tidaklah mudah. Butuh waktu dan latihan yang terus menerus, pengarahan dan bimbingan yang efektif agar potensi kreativitas siswa berkembang hingga siswa mampu menghasilkan tulisan puisi yang bermutu. Namun pada 
kenyataannya, berdasarkan hasil observasi yang dilaksanakan pada Tanggal 19 Maret 2018 di SDN Muktiwari 02 Kecamatan Cibitung Kabupaten Bekasi menunjukkan bahwa kemampuan menulis puisi siswa kelas $\mathrm{V}$ masih rendah, pembelajaran menulis puisi terkesan membosankan, Guru menyajikan pembelajaran dengan cara hanya menyuruh siswa menulis tetapi siswa tidak digiring betul-betul agar menghasilkan puisi yang baik. Sehingga siswa merasa kurang kondusif dan tidak menikmati proses pembelajaran yang berlangsung.

Metode pembelajaran yang menarik merupakan faktor penting dalam keberhasilan proses pembelajaran sehingga siswa tidak merasa bosan dan siswa lebih jelas dalam menerima materi pembelajaran, serta memungkinkan siswa menguasai tujuan pembelajaran yang lebih baik. Oleh karena itu, pengoptimalisasian metode dalam pembelajaran menulis puisi yang dilakukan oleh guru sangatlah diperlukan. Dalam penelitian ini penulis menerapkan metode sugestopedia sebagai alternatif untuk mengoptimalkan pembelajaran menulis puisi bagi siswa Sekolah Dasar khususnya kelas V. Dengan demikian, menulis bukanlah pelajaran yang harus ditakuti lagi oleh siswa khususnya pembelajaran menulis puisi.

Metode yang digunakan adalah dengan menerapkan konsep sugestopedia yang berlandaskan pada sugesti yakni suatu konsep yang menyajikan suatu pengetahuan bahwa manusia bisa diarahkan untuk melakukan sesuatu dengan memberikannya sugesti. Pikiran harus dibuat setenang mungkin, santai, dan terbuka sehingga bahan-bahan yang merangsang saraf penerimaan bisa dengan mudah diterima dan dipertahankan untuk jangka waktu yang lama dalam pemprosesan pemahaman bahasa (Dardjowidjojo, 1992:63).
Melalui metode sugestopedia siswa dapat berlatih menulis puisi dengan cara mengkondisikan siswa dengan sugesti berupa kata-kata sehingga siswa dalam keadaan yang nyaman dan larut dalam keadaan yang sesuai dengan disugestikan. Dalam keadaan ini, siswa mudah untuk menemukan kata-kata dalam puisi. Tarigan (2009, 137) menyatakan bahwa metode sugestopedia merupakan cara pemusatan perhatian dan pikiran yang dapat membantu para pembelajar mengelola bawah sadar mereka dan menyimpan kosakata dan aturan kebahasaan yang pernah diajarkan kepada mereka.

Sugestopedia adalah metode pengajaran yang didasarkan pada proses cara berpikir dan bertindak tentang bagaimana otak manusia bekerja dan bagaimana kita belajar paling efektif. Suatu konsep yang menyuguhkan suatu pandangan bahwa manusia bisa diarahkan untuk melakukan sesuatu dengan memberikannya sugesti (Richard, J dan Rodgers, T.S. 1993:142). Lozanov percaya bahwa cara-cara pengendoran otot-otot dalam otak dan pemusatan perhatian atau pikiran akan membantu para pembelajar membuka sumber-sumber bawah sadar mereka dan memperoleh, menguasai jumlah kosa kata yang lebih banyak dan juga pengaturan pola dalam bahasa secara sintagmatis yang lebih mantap daripada yang mungkin pernah mereka pikirkan (Richards dan Rodgers, 1999:142-143). Hal ini menjelaskan bahwa metode sugestopedia dapat mengembangkan ide dan membantu siswa dalam memproduksi kata dan menemukan kata selama proses pembelajaran sehingga dapat memudahkan siswa dalam mengembangkan ide dan menemukan katakata yang tepat sehingga menghasilkan puisi yang indah. 
Seyogyanya guru dalam menerapkan metode sugestopedia berupaya menghilangkan pengaruh yang negatif atau rasa takut yang dapat menghambat belajar siswa; misalnya perasaan tidak mempunyai kemampuan, takut berbuat kesalahan, tidak terbiasa dengan hal yang baru atau tidak dikenal.. Salah satu caranya yang dapat dilakukan oleh guru adalah dengan menunjukkan sikap berwibawa dan memiliki strategi kemampuan serta menjaga reputasi dalam pembelajaran.

Menurut Dardjowidjojo (Fahriaty, Eti. 2013: 91) Pada pelaksanaan strategi sugestopedia, siswa diminta melakukan berdiam diri dengan sikap rileks (bernapas dalam-dalam) yang berguna bagi hipermnestik yakni kemampuan supermemori yang luar biasa. Lozanov yang mengembangkan metode ini percaya bahwa otak manusia dapat dipercepat kemampuan memorinya dengan memberikan teknik berdiam diri seperti relaksasi, bernapas secara ritmik, dan mendengar bacaan yang dibaca oleh guru yang sejalan dengan musik yang diputar. Pada strategi sugestopedia diperlukan pula suatu atmosfir fisik yang mendukung proses belajar-mengajar. Atmosfir ini dibuat dengan memilih ruangan yang nyaman terhadap proses pembelajaran. Ruang belajar sugestopedia bukan suatu ruang kelas biasa tetapi suatu ruangan dengan kursi yang nyaman diduduki dan diatur supaya santai (Dardjowidjojo,1992:63). Pada tiap pelajaran diberikan pula latar belakang musik yang sesuai dengan jiwa bahan yang diberikan. Baik ruang maupun musik ini semuanya dimaksudkan untuk menenangkan pikiran siswa sehingga dengan mudah menerima bahan yang diberikan.

Berangkat dari pemikiran hasil observasi pendahuluan yang dilakukan pada tanggal
19 Maret 2018 di SDN. Muktiwari 02 Kecamatan Cibitung Kabupaten Bekasi di atas, penelitian ini terfokus pada penerapan metode pembelajaran sugestopedia dengan judul, "Penerapan metode sugestopedia untuk Meningkatkan Kemampuan Menulis Puisi Siswa Kelas V Sekolah Dasar" (Penelitian Tindakan Kelas yang dilakukan pada kelas V SDN. Muktiwari 02 Kecamatan Cibitung Kabupaten Bekasi Tahun Pelajaran 2017/2018).

Berdasarkan uraian di atas, tujuan penelitian ini adalah adalah untuk mendeskripsikan proses pembelajaran menulis puisi siswa kelas V SDN Muktiwari 02 Kecamatan Cibitung Bekasi dengan menggunakan metode sugestopedia serta untuk mengetahui kemampuan menulis puisi sebelum dan setelah menerapkan metode sugestopedia.

\section{MATERI DAN METODE}

\section{Jenis Penelitian}

Penelitian yang digunakan dalam penelitian ini adalah penelitian tindakan kelas (classroom action research). Ebbbut (Wiriaatmadja, R, 2014: 12) menyatakan penelitian tindakan kelas merupakan upaya guru atau praktisi dalam memperbaiki dan atau meningkatkan mutu pembelajaran di kelas dengan melakukan tindakantindakan dalam proses pembelajaran, berdasarkan refleksi mengenai hasil dari tindakan-tindakan tersebut. Dengan menggunakan penelitian tindakan kelas, seorang guru dapat memperbaiki kinerjanya dan dapat memecahkan masalah-masalah yang terjadi di dalam kelas dengan cara melihat kembali apa yang sudah dilakukannya selama di dalam kelas

Variable yang digunakan dalam penelitian ini adalah metode pembelajaran 
sugestopedia sebagai variable predictor dan kemampuan menulis puisi sebagai variable kriterium. Metode sugestopedia sebagai treatment dalam meningkatkan kemampuan menulis puisi. Dan tes kemampuan menulis puisi sebagai penentu keberhasilan pembelajaran menulis puisi. Adapun desain perbaikan pembelajaran dengan menggunakan alur penelitian tindakan kelas terdapat pada Gambar 1.

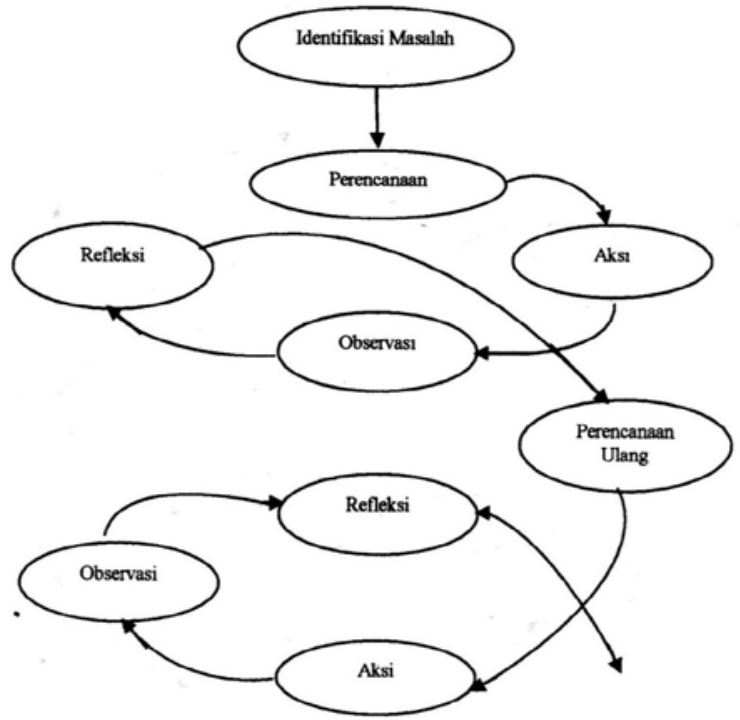

Gambar 1 Alur PTK menurut Taggart (Wiriaatmadja, R, 2014: 66)

Tahapan yang dijelaskan pada gambar di atas, alur penelitian tersebut akan dipergunakan sebagai langkah dalam penelitian yaitu dilaksanakan melalui proses pengkajian berdaur, yang terdiri dari empat tahap, yaitu merencanakan, melakukan tindakan, mengamati, dan melakukan refleksi.

Dalam merencanakan empat tahapan tersebut, yang perlu dilakukan terlebih dahulu adalah identifikasi masalah yaitu merumuskan masalah yang akan dijadikan sebagai objek penelitian, setelah masalah dirumuskan langkah selanjutnya adalah menentukan perencanaan yaitu proses penyusunan rencana tindakan yang akan dilakukan untuk memecahkan masalah yang dilakukan secara sistematik, kemudian tahap pelaksanaan yang dilakukan peneliti sesuai dengan rancangan yang telah dibuat sebelumnya, sebagai upaya perbaikan dalam proses pembelajaran. Pada saat proses pembelajaran, peneliti melakukan observasi guna mengamati proses, hasil ataupun dampak dari pengembangan tindakan sebelumnya, baik terhadap siswa dan kinerja guru dalam proses pembelajaran, dan juga suasana kelas secara keseluruhan. Hasil observasi yang telah diamati selanjutnya digunakan untuk menata kembali langkahlangkah refleksi dan revisi pada perencanaan tindakan selanjutnya. Dari konsep PTK di atas, dapat diimplementasikan ke dalam langkahlangkah pembelajaran dengan menggunakan metode pembelajaran sugestopedia yang diadopsi dari Lozanov seperti pada Gambar 2.

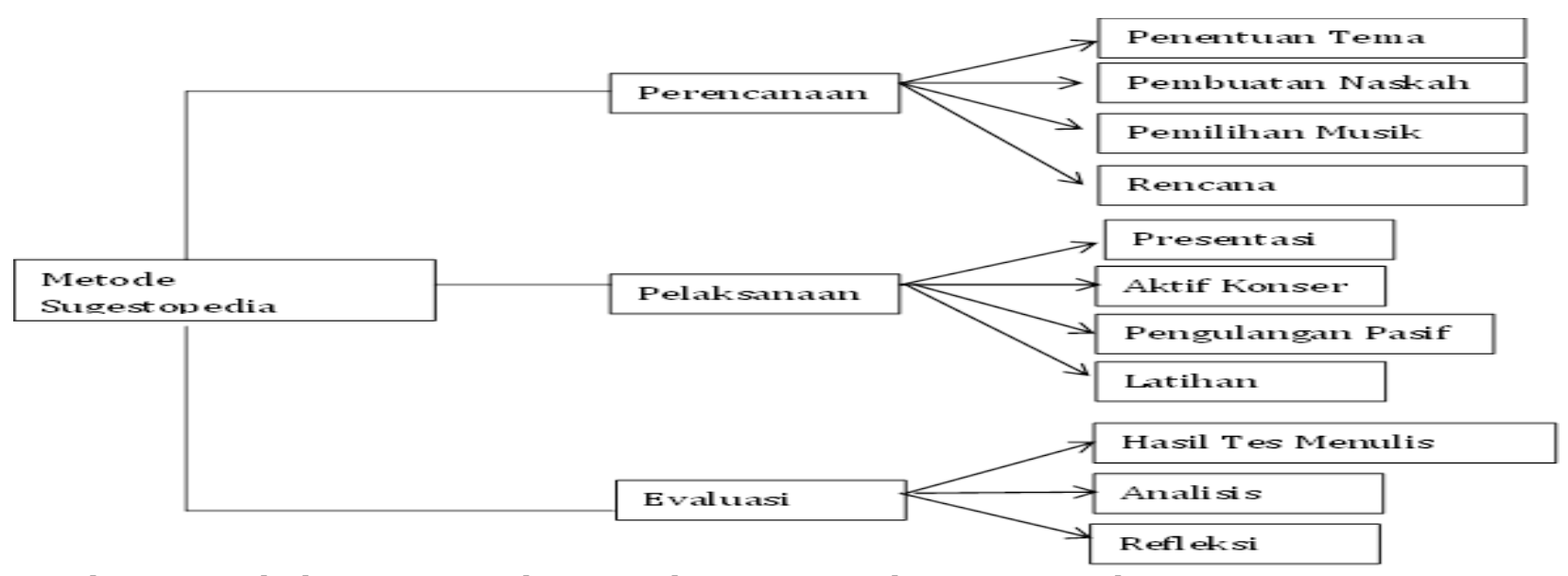

Gambar 2 Pembelajaran menulis puisi dengan metode sugestopedia 


\section{Waktu dan Tempat Penelitian}

Penelitian tindakan ini dilaksanakan pada kelas V Sekolah Dasar semester I Tahun Pelajaran 2017/2018 dimulai pada bulan Juni 2018. Tempat Penelitian tindakan kelas ini dilaksanakan dilakukan di SDN. Muktiwari 02 yang beralamat di Kampung Bulak Kunyit Rt. 04/02 Desa Muktiwari kecamatan Cibitung kabupaten Bekasi.

\section{Target/Subjek Penelitian}

Subjek penelitian ini adalah siswa kelas $\mathrm{V}$ SD Negeri Muktiwari 02, Kecamatan Cibitung Kabupaten Bekasi sebanyak 30 siswa yang terdiri dari 12 siswa laki-laki dan 18 siswa perempuan. Sedangkan objek penelitian ini, yaitu kemampuan menulis puisi. Penelitian ini bersifat kolaborator yang melibatkan guru kelas sebagai kolaborator, yaitu guru kelas $\mathrm{V}$.

\section{Prosedur Penelitian}

Penelitian tindakan ini dilakukan dalam 3 siklus. Alokasi waktu untuk setiap pertemuan 2 x 45 menit. Dalam pelaksanaannya, masing-masing siklus mengikuti tahap-tahap yang ada dalam penelitian tindakan kelas, yaitu tahap pertama perencanaan, tahap kedua implementasi tindakan, tahap ketiga pengamatan, dan tahap terakhir refleksi.

\section{Tahap Perencanaan}

1) Peneliti bersama guru menentukan materi yang akan diajarkan pada siklus I yaitu menulis puisi dengan tema yang ditentukan.

2) Mempersiapkan Rencana Pelaksanaan Pembelajaran (RPP), lembar observasi siswa dan guru, tes evaluasi, dan kamera untuk mendokumentasikan aktivitas guru dan siswa pada saat proses pembelajaran berlangsung.

\section{Tahap Tindakan}

Langkah-langkah proses pembelajaran menggunakan metode sugestopedia meliputi:

1) Presentasi: Dalam tahap ini siswa dibuat rileks dan diberi sugesti positif bahwa belajar itu mudah dan menyenangkan

2) Aktif konser: Kegiatan yang aktif antara guru dan siswa dalam belajar. Dalam tahap ini guru memberikan materi dan membacakan teks narasi secara dramatik pada para siswa dengan musik diputar sebagai latarnya, biasanya dengan musik klasik atau romantik.

3) Pengulangan pasif: guru memberi kesempatan siswa untuk memahami apa yang dipelajari dalam tahap aktif konser. Alunan musik dapat deperdengarkan dalam tahap ini.

4) Latihan: siswa menulis puisi sesuai dengan tema yang ditentukan.

\section{Tahap Observasi}

Observasi yang dilakukan disini adalah pengamatan yang dilakukan terhadap kegiatan siswa dan guru selama penelitian berlangsung.

\section{Tahap Refleksi}

Untuk merefleksi hasil penelitian pada siklus I, peneliti menganalisis dan mengkaji hasil puisi, perilaku siswa dan cara mengajar guru selama pelaksanaan siklus I. Hasil dari siklus pertama ini dijadikan dasar untuk melakukan tindak lanjut pada siklus yang kedua.

\section{Data, Instrumen, dan Teknik Pengumpulan Data}

Instrumen pengumpulan data yang digunakan dalam penelitian ini, meliputi: 1) observasi, 2) tes hasil kemampuan menulis puisi. 


\section{Observasi}

Observasi merupakan upaya yang dilakukan dalam pelaksanaan PTK untuk mengenali, dan mendokumentasikan segala peristiwa dan kegiatan yang terjadi selama tindakan yang meliputi aktivitas siswa, cara guru mengajar, media yang digunakan, sumbersumber pembelajaran metode yang digunakan. Observasi dalam konteks penelitian ini merupakan instrumen pengumpulan data yang bertujuan mencatat informasi mengenai kegiatan guru dan kegiatan siswa serta mengukur tingkah laku siswa dalam proses pembelajaran menulis puisi di SDN Muktiwari 02 Cibitung Kabupaten Bekasi.

\section{Tes Hasil Belajar}

Teknik tes merupakan salah satu alat ukur untuk mengetahui kemampuan seseorang terhadap suatu permasalahan dan mengukur seseorang dalam melakukan sesuatu. Data yang dihimpun dalam penelitian ini adalah hasil evaluasi berupa tes yang berbentuk nilai yang didapat oleh siswa yang dijadikan subjek penelitian. Dalam penelitian ini menggunakan instrumen tes hasil kemampuan menulis puisi dengan menggunakan metode sugestopedia.

\section{Teknik Analisis Data}

Analisis data dalam penelitian ini menggunakan analisis kualitatif, di mana analisis dilakukan secara terus menerus dari awal sampai akhir pelaksanaan penelitian. Analisis kualitatif untuk memberikan interprestasi secara konseptual terhadap kinerja guru, yang berupa kemampuan guru dalam menerapkan pembelajaran menulis puisi dengan menerapkan metode pembelajaran sugestopedia, aktivitas siswa, serta pola interaksi dalam proses pembelajaran.

\section{Pengumpulan Data}

Data yang telah terkumpul kemudian dikategorisasikan. Kategorisasi data dilakukan dengan mengelompokkan sebagai berikut: a) berupa informasi tentang latar fisik kelas, para pelaku yang dalam hal ini adalah guru dan siswa, b) meliputi informasi tentang interaksi edukatif antara guru dan siswa, siswa dengan siswa, maupun perubahan-perubahan yang terjadi selama proses pembelajaran berlangsung, c) meliputi informasi tentang tindakan para pelaku yaitu guru dan siswa.

\section{Mengolah Data dari Hasil Pengamatan Observer}

Dari hasil pengamatan guru dalam mengelola pembelajaran dengan metode sugestopedia, dianalisis dengan menghiung rata-rata nilai setiap indikator prngrlolaan selama tiga siklus. Hasil pengamatan observasi aktivitas guru dihitung dengan rumus:

$$
S=\frac{O}{I A}
$$

Keterangan: $\mathrm{S}=$ nilai dari observer; $0=$ jumlah nilai aspek yang diperoleh; JA = jumlah seluruh aspek

Dalam menghitung hasil pengamatan guru dalam mengelola pembelajaran dengan metode sugestopedia maka dapat dilihat pada tabel 1 .

\section{Hasil Belajar Secara Individu}

Dalam menghitung hasil belajar menulis puisi secara individu dilihat melalui lima aspek yaitu Tema, diksi, imaji, dan bahasa figuratif. Maka untuk melihat hasil belajar menulis puisi setiap individu yaitu pada Tabel 2. 
Tabel 1 Observasi pengelolaan pembelajaran guru dengan metode sugestopedia

\begin{tabular}{|c|c|c|c|}
\hline \multirow[t]{2}{*}{ No } & \multirow[t]{2}{*}{ Aspek } & \multicolumn{2}{|l|}{ Skor } \\
\hline & & $\begin{array}{lll}1 & 2 & 3 \\
\end{array}$ & 4 \\
\hline 1 & $\begin{array}{l}\text { Memulai pembelajaran } \\
\text { dengan memberi } \\
\text { motivasi pada siswa }\end{array}$ & & \\
\hline 2 & $\begin{array}{l}\text { Menguasai dan } \\
\text { menyajikan konsep } \\
\text { materi pembelajaran }\end{array}$ & & \\
\hline 3 & $\begin{array}{l}\text { Mengarahkan perhatian } \\
\text { siswa dan kontak mata }\end{array}$ & & \\
\hline 4 & $\begin{array}{l}\text { Antusiasme, penamapilan } \\
\text { menarik }\end{array}$ & & \\
\hline 5 & $\begin{array}{lr}\text { Mengaplikasikan } & \text { setiap } \\
\text { langkah-langkah } & \text { metode } \\
\text { sugestopedia } & \text { dalam } \\
\text { kegiatan } & \text { belajar } \\
\text { mengajar } & \end{array}$ & & \\
\hline 6 & $\begin{array}{l}\text { Keterampilan } \\
\text { penggunaan media dalam } \\
\text { penerapan metode } \\
\text { sugestopedia }\end{array}$ & & \\
\hline 7 & $\begin{array}{l}\text { Memberikan kesempatan } \\
\text { kepada siswa untuk } \\
\text { bertanya }\end{array}$ & & \\
\hline 8 & Memberikan latihan & & \\
\hline 9 & $\begin{array}{l}\text { Membimbing siswa yang } \\
\text { kurang paham materi } \\
\text { Total } \\
\text { Skor }\end{array}$ & & \\
\hline
\end{tabular}

Tabel 2 Aspek penilaian menulis puisi

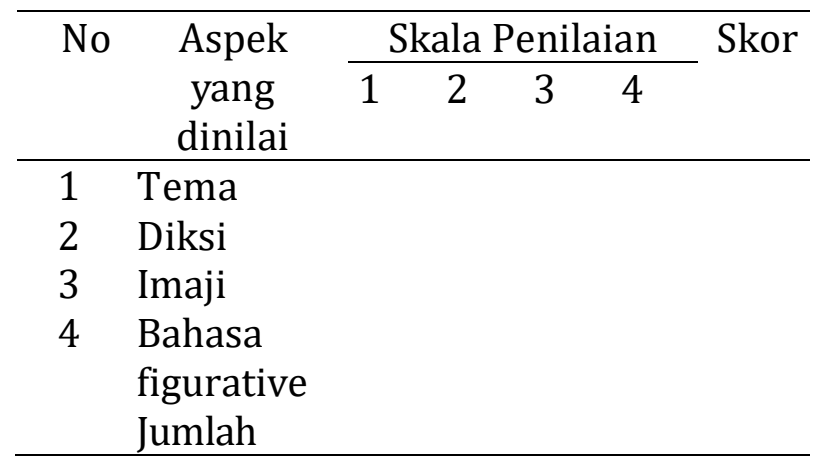

Rumus penilaian: skor Perolehan X 100 skor maksimal
Tabel 3 Kategori hasil belajar kognitif

\begin{tabular}{cl}
\hline \multicolumn{1}{c}{ Rentang nilai } & \multicolumn{1}{c}{ Kategori } \\
\hline $80-100$ & Sangat baik \\
$66-79$ & Baik \\
$56-65$ & Cukup \\
$40-55$ & Kurang \\
$30-39$ & Sangat kurang \\
\hline \multicolumn{2}{l}{ Sumber: Arikunto (2006: 489$).$}
\end{tabular}

\section{Rata-rata Kelas}

Selain pengumpulan data di atas, data hasil penelitian dapat diperoleh melalui rata-rata kelas pada masing-masing siklus, yaitu dengan menggunakan rumus yang dikutip dari Nana Sudjana (2005: 138) sebagai berikut.

$$
\begin{aligned}
& \quad \bar{x}=\frac{\sum x}{n} \\
& \text { Keterangan: } \\
& \sum \begin{array}{l}
\bar{x}=\text { Rata }- \text { rata } \text { kelas; } \\
\text { siswa. }
\end{array}
\end{aligned}
$$

\section{HASIL DAN PEMBAHASAN}

\section{Kondisi Awal}

\section{Proses dan Hasil Kemampuan Menulis Puisi pada Kondisi Awal}

Pembelajaran pada kondisi awal menunjukkan proses pembelajaran belum optimal yaitu selama proses pembelajaran berlangsung guru masih menggunakan metode ceramah dan mendominasi kelas sehingga siswa kurang aktif, bahkan ada beberapa siswa yang malu saat dipanggil ke depan atau takut menjawab pertanyaan guru sehingga siswa terlihat diam. Selain itu juga konsentrasi siswa kurang karena saat penyampaian materi siswa terlihat mengantuk bahkan ada siswa yang menguap saat guru menyampaikan materi. Begitupun minat siswa yang terlihat pada pra siklus masih terlihat kurang, siswa terlihat bosan dan ada siswa yang mengobrol saat proses pembelajaran. 
Berdasarkan deskripsi hasil pembelajaran dan observasi terhadap guru dan siswa, umumnya pembelajaran masih belum optimal. Kemampuan menulis puisi siswa yang masih di bawah rata-rata, guru kurang menguasai kelas dan kurang melibatkan siswa dalam kegiatan pembelajaran. Selanjutnya, untuk mengukur pemahaman siswa akan diadakan tes menulis puisi. Tes pada kondisi awal ini merupakan kemampuan menulis puisi sebelum dilakukan tindakan menerapkan metode sugestopedia.

Tes kemampuan ini bertujuan untuk mengetahui kondisi awal kemampuan menulis puisi sisw kelas V SD Negeri Muktiwari 02. Jumlah siswa yang mengikuti tes pada kondisi awal ini adalah 30 orang, dengan hasil yang dapat dilihat pada tabel 4 .

Tabel 4 Kategorisasi kemampuan menulis puisi pra siklus

\begin{tabular}{clrrll}
\hline No. & Rentang Nilai & Jumlah & \multicolumn{1}{c}{$\%$} & Kategori & Rata-rata \\
\hline 1 & $80-100$ & 0 & 0 & Sangat baik & $\bar{x}=\frac{1556,25}{30}=51,88$ \\
2 & $66-79$ & 3 & 10 & Baik & \\
3 & $56-65$ & 8 & 26,7 & Cukup & \\
4 & $40-55$ & 16 & 53,3 & Kurang & \\
5 & $30-39$ & 3 & 10 & Sangat kurang & \\
\hline
\end{tabular}

Dari tabel 4 diperoleh data tentang kemampuan awal siswa dalam menulis puisi. Jumlah rata-rata hitung yang diperoleh siswa dari keseluruhan aspek yang dinilai adalah 51,88. Hal ini menunjukkan bahwa nilai rata-rata siswa masih di bawah KKM yaitu 70. Dengan demikian dapat dinyatakan bahwa sebagian besar siswa masih termasuk ke dalam kategori kurang maka perlu diadakan perbaikan untuk meningkatkan nilai siswa. Tindakan yang dilakukan salah satunya adalah penerapan metode sugesopedia dalam pembelajaran menulis puisi. Kemampuan awal siswa dalam menulis puisi terdapat pada Gambar 3.

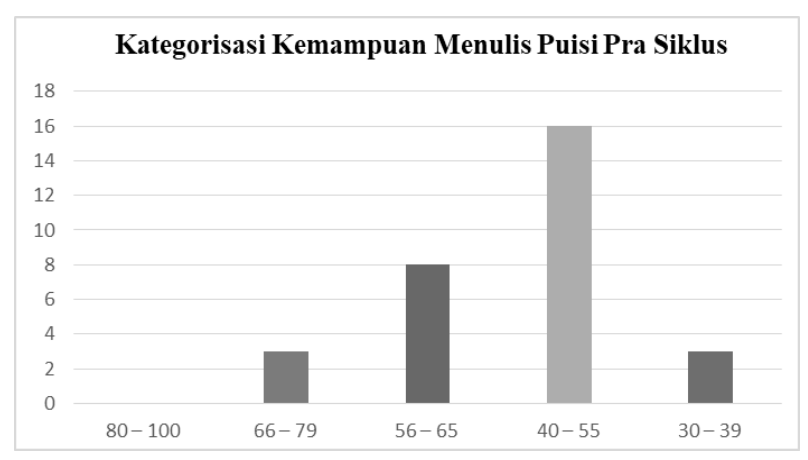

Gambar 3 Kategorisasi kemampuan menulis puisi pra siklus

\section{Siklus I}

\section{Proses dan Hasil Keterampilan Menulis Puisi pada Siklus I}

\section{Tahap Perencanaan}

Tahap perencanaan pada siklus I dilakukan dengan menyiapkan perangkat pembelajaran yang akan digunakan pada siklus I. Pada tahap perencanaan ini pula dibuat antara lain lembar pengamatan untuk mengamati aktivitas siswa dan aktivitas guru dalam pembelajaran.

\section{Tahap Tindakan dan Observasi}

Pengelolaan pembelajaran guru dengan metode sugestopedia dikategorikan cukup baik. Guru membacakan narasi dengan mengikuti pola irama iringan musik sehingga dapat menyentuh perasaan siswa. Akan tetapi media yang digunakan guru masih belum maksimal karena guru menggunakan handphone sehingga suaranya tidak terdengar saat siswa berisik. Selain itu juga guru dalam mengarahkan perhatian dan kontak mata masih kurang. Guru belum bisa mengkondisikan siswa 
yang mengganggu temannya saat proses sugestopedia sehingga ada beberapa siswa yang tidak menghayati narasi.

Berdasarkan deskripsi hasil pembelajaran dan observasi terhadap guru dan siswa belum maksimal. Guru menerapkan metode sugestopedia dengan media yang terbatas dan aktivitas siswa masih terlihat kurang serius. Berikut adalah data hasil observasi yang dilakukan pada siklus I. Sesuai yang telah direncanakan observer yang dilakukan adalah terhadap guru selama pembejaran, aktivitas siswa selama pembelajaran, dan hasil belajar dengan metode sugestopedia.

Tabel 5 Observasi pengelolaan pembelajaran guru dengan metode sugestopedia siklus I

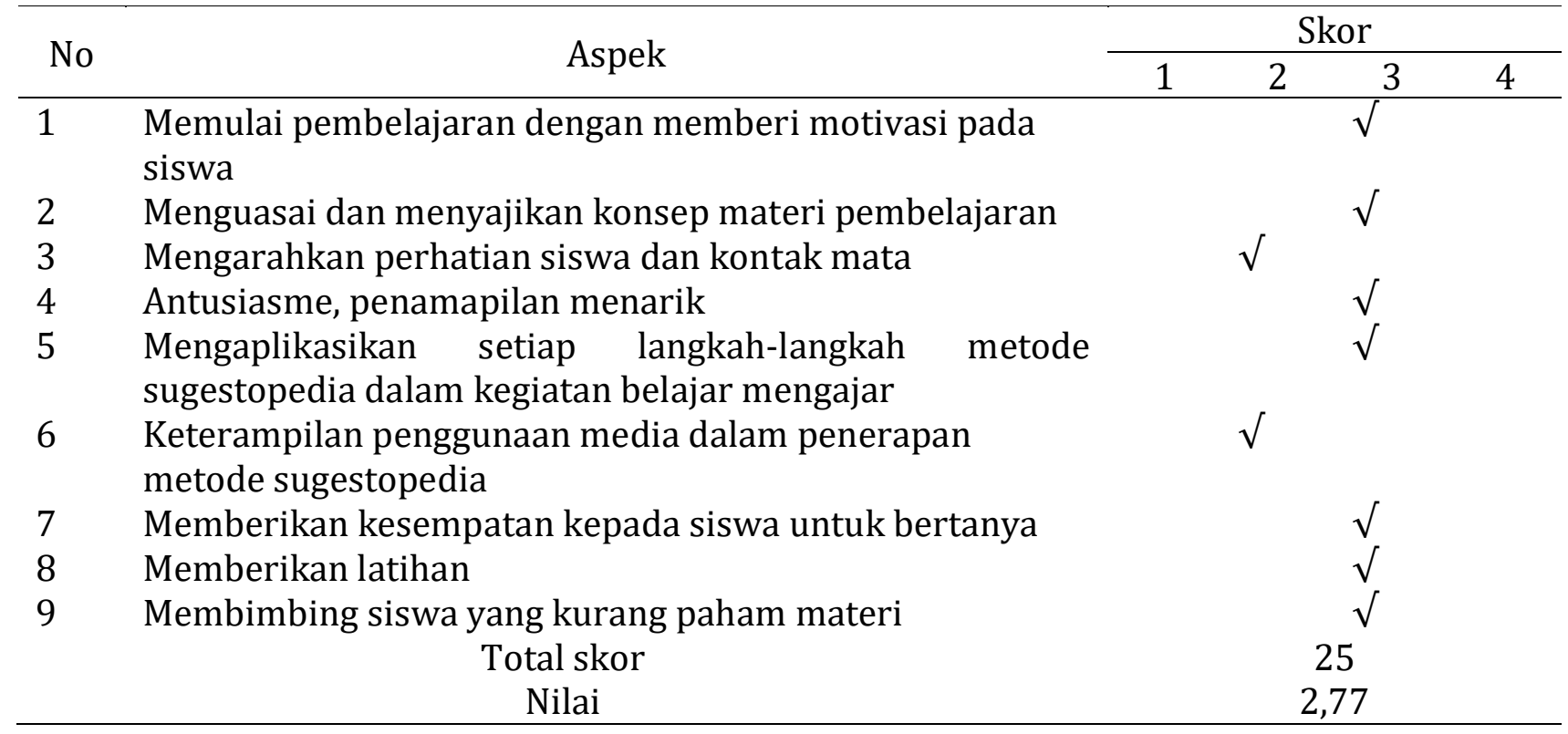

Berdasarkan tabel 5 dapat dilihat pengelolaan pembelajaran guru dengan metode sugestopedia dikategorikan cukup baik. Secara umum dari tiap aspek yang diamati guru melakukan dengan baik. Guru membacakan narasi dengan mengikuti pola irama iringan musik sehingga dapat menyentuh perasaan siswa. Akan tetapi media yang digunakan guru masih belum maksimal karena guru menggunakan handphone sehingga suaranya tidak terdengar saat siswa berisik. Selain itu juga guru dalam mengarahkan perhatian dan kontak mata masih kurang. Guru belum bisa mengkondisikan siswa yang mengganggu temannya saat proses sugestopedia sehingga ada beberapa siswa yang tidak menghayati narasi. Selanjutnya, untuk mengukur pemahaman siswa akan diadakan tes menulis puisi. Tes pada siklus I dapat dilihat pada tabel 6 .

Tabel 6 Kategorisasi kemampuan menulis puisi siklus I

\begin{tabular}{clllll}
\hline No. & \multicolumn{1}{c}{ Rentang Nilai } & Jumlah & \multicolumn{1}{c}{ Kategori } & Rata-rata \\
\hline 1 & $80-100$ & 4 & 13,33 & Sangat baik & $\bar{x}=\frac{1875}{30}=62,5$ \\
2 & $66-79$ & 8 & 26,67 & Baik & \\
3 & $56-65$ & 12 & 40 & Cukup & \\
4 & $40-55$ & 5 & 16,67 & Kurang & \\
5 & $30-39$ & 1 & 3,333 & Sangat kurang & \\
\hline
\end{tabular}


Dari tabel 6 diperoleh data tentang kemampuan menulis puisi. Sebagian besar siswa mendapatkan kategori cukup dan jumlah rata-rata hitung yang diperoleh siswa dari keseluruhan aspek yang dinilai adalah 62,5. Hal ini menunjukkan bahwa nilai rata-rata siswa masih di bawah KKM yaitu 70. Kemampuan awal siswa dalam menulis puisi pada siklus I dapat digambarkan pada grafik seperti pada Gambar 4.

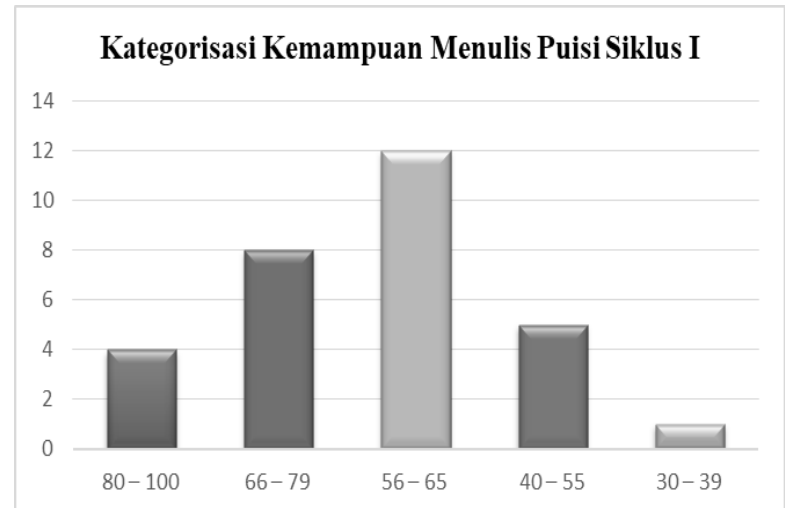

Gambar 4 Kategorisasi kemampuan menulis puisi siklus I

\section{Tahap Refleksi}

Pada siklus I pembelajaran menulis puisi belum sepenuhnya berjalan dengan baik dan optimal. Hasil tes tindakan siklus I sudah mengalami peningkatan akan tetapi masih ada beberapa siswa yang belum mencapai standar. Berikut refleksi berdasarkan hasil observasi yang telah dilaksanakan pada siklus I di antaranya yaitu sebagai berikut.

1) Guru akan membuat teks narasi dengan menggunakan bahasa yang ringan, singkat dan padat.

2) Guru akan mengubah posisi tempat duduk siswa menjadi tidak berdekatan.

3) Guru akan menggunakan laptop dan speaker sebagai pengeras suara.

4) Guru akan lebih memotivasi siswa dalam proses pembelajaran.
5) Guru akan membahas lebih dalam mengenai penggunaan diksi, imaji dan bahasa figuratif.

\section{Siklus II}

\section{Proses dan Hasil Keterampilan Menulis Puisi pada Siklus II}

\section{Tahap Perencanaan}

Dari hasil refleksi siklus I, ada beberapa kendala yang dihadapi. Maka peneliti berupaya memperbaiki dan mengatasi kendala-kendala yang terjadi pada siklus I agar tidak terulang pada siklus II. Sebelum melaksanakan siklus II guru menyiapkan rencana pelaksanaan pembelajaran dengan menggunakan metode sugestopedia, membuat teks narasi, lembar kerja kemampuan menulis puisi, lembar observasi guru dan siswa, menyediakan laptop, speaker dan mencari musik yang diterapkan pada metode sugestopedia.

\section{Tahap Tindakan dan Observasi Siklus II}

Guru dengan metode sugestopedia terdapat peningkatan. Secara umum dari tiap aspek yang diamati guru melakukan dengan baik. Guru membacakan narasi dengan mengikuti pola irama iringan musik sehingga dapat menyentuh perasaan siswa. Keaktifan siswa dalam bertanya dan mersepon guru mulai meningkat, meskipun terdapat siswa yang malu masih perlu bimbingan guru.

Berdasarkan deskripsi hasil pembelajaran dan observasi terhadap guru dan siswa cukup baik. Guru menerapkan metode sugestopedia dengan baik dan sebagian besar siswa terlihat antusias dalam mengikuti pelajaran menulis puisi dengan metode sugestopedia hal ini dapat digambarkan pada tabel 7 . 
Tabel 7 Observasi pengelolaan pembelajaran guru dengan metode sugestopedia siklus II

\begin{tabular}{|c|c|c|c|c|c|}
\hline \multirow{2}{*}{ No } & \multirow{2}{*}{ Aspek } & \multicolumn{4}{|c|}{ Skor } \\
\hline & & 1 & 2 & 3 & 4 \\
\hline 1 & $\begin{array}{l}\text { Memulai pembelajaran dengan memberi motivasi pada } \\
\text { siswa }\end{array}$ & & & & $\sqrt{ }$ \\
\hline 2 & Menguasai dan menyajikan konsep materi pembelajaran & & & & $\sqrt{ }$ \\
\hline 3 & Mengarahkan perhatian siswa dan kontak mata & & & $\sqrt{ }$ & \\
\hline 4 & Antusiasme, penamapilan menarik & & & $\sqrt{ }$ & \\
\hline 5 & $\begin{array}{l}\text { Mengaplikasikan setiap langkah-langkah metode } \\
\text { sugestopedia dalam kegiatan belajar mengajar }\end{array}$ & & & $\sqrt{ }$ & \\
\hline 6 & $\begin{array}{l}\text { Keterampilan penggunaan media dalam penerapan } \\
\text { metode sugestopedia }\end{array}$ & & & & $\sqrt{ }$ \\
\hline 7 & Memberikan kesempatan kepada siswa untuk bertanya & & & $\sqrt{ }$ & \\
\hline 8 & Memberikan latihan & & & $\sqrt{ }$ & \\
\hline 9 & Membimbing siswa yang kurang paham materi & & & $\sqrt{ }$ & \\
\hline & Total skor & & & & \\
\hline & Nilai & & & & \\
\hline
\end{tabular}

Berdasarkan tabel 7 dapat dilihat pengelolaan pembelajaran guru dengan metode sugestopedia terdapat peningkatan. Secara umum dari tiap aspek yang diamati guru melakukan dengan baik. Guru membacakan narasi dengan mengikuti pola irama iringan musik sehingga dapat menyentuh perasaan siswa. Guru juga memberikan kesempatan untuk siswa bertanya dan menstimulus siswa yang pasif dengan membimbing siswa saat maju ke depan dalam membaca puisi. Selanjutnya, untuk mengukur pemahaman siswa akan diadakan tes menulis puisi. Tes pada siklus II dapat dilihat pada Tabel 8.

Tabel 8 Kategorisasi kemampuan menulis puisi siklus II

\begin{tabular}{clrrlc}
\hline No. & Rentang Nilai & Jumlah & $\%$ & \multicolumn{1}{c}{ Kategori } & Rata-rata \\
\hline 1 & $80-100$ & 7 & 23,33 & Sangat baik & $\bar{x}=\frac{2068,75}{30}=68,96$ \\
2 & $66-79$ & 11 & 36,67 & Baik & \\
3 & $56-65$ & 11 & 36,67 & Cukup & \\
4 & $40-55$ & 1 & 3,333 & Kurang & \\
5 & $30-39$ & 0 & 0 & Sangat kurang & \\
\hline
\end{tabular}

Dari tabel 8 diperoleh data tentang kemampuan menulis puisi siswa pada siklus II. Jumlah rata-rata hitung yang diperoleh siswa dari keseluruhan aspek yang dinilai adalah 68,95. Hasil ini menunjukkan peningkatan dibandingkan hasil pada siklus I. Kemampuan awal siswa dalam menulis puisi pada siklus II dapat digambarkan pada grafik seperti pada Gambar 5.

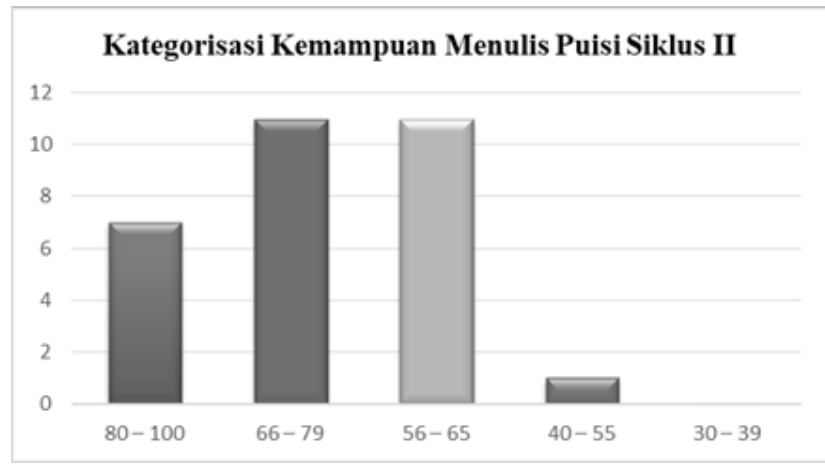

Gambar 5 Kategorisasi kemampuan menulis puisi siklus II 


\section{Tahap Refleksi Siklus II}

Berdasarkan hasil observasi yang telah dilaksanakan pada siklus II terdapat beberapa kendala dalam menerapkan metode sugestopedia, berikut refleksi guru di antaranya, yaitu:

1) Guru dalam menerapkan metode sugestopedia akan membacakan teks narasi lebih dramatis lagi sehingga akan lebih memunculkan daya bayang siswa. Untuk meningkatkan bahasa figuratif, guru akan meminta siswa membuat puisi secara berantai sehingga diharapkan semua siswa paham dalam menggunakan bahasa figuratif pada menulis puisi.

2) Guru akan lebih memotivasi siswa yang pemalu dengan sebutan "pemberani".

3) Guru akan mengubah kelas tanpa kursi dan meja, siswa akan duduk melingkar sehingga semua siswa akan terkontrol lebih baik lagi dan diharapkan semua siswa bisa lebih konsentrasi.

\section{Siklus III}

\section{Proses dan Hasil Keterampilan Menulis Puisi pada Siklus III}

\section{Tahap Perencanaan}

Pada siklus III guru menyiapkan rencana pembelajaran, contoh puisi yang mengandung bahasa figuratif, teks narasi, dan musik. Untuk menjaga konsentrasi siswa, guru akan mengubah kelas tanpa kursi dan meja, guru akan membentuk siswa dalam bentuk lingkaran sehingga siswa terlihat semua dari jangkauan guru. dan bagi siswa yang pemalu, guru akan memanggilnya "si pemberani".

\section{Tahap Tindakan dan Observasi Siklus III}

Aktivitas guru dengan metode sugestopedia terdapat peningkatan. Secara umum dari tiap aspek yang diamati guru melakukan dengan baik. Guru membacakan narasi dengan mengikuti pola irama iringan musik sehingga dapat menyentuh perasaan siswa. Siswa juga membentuk lingkaran sehingga semua siswa dapat dikontrol guru saat siswa berisik ataupun siswa yang pasif segera diberikan bimbingan. Siswa pun terlihat antusias dan aktif dalam mengikuti proses pembelajaran. Pada siklus ke III ini siswa lebih berani untuk merespon pertanyaan guru dan konsentrasi saat mendengarkan materi dan proses pembacaan teks narasi, hal ini dapat digambarkan pada Tabel 9.

Berdasarkan tabel 9 dapat dilihat pengelolaan pembelajaran guru dengan metode sugestopedia terdapat peningkatan. Secara umum dari tiap aspek yang diamati guru melakukan dengan baik. Guru membacakan narasi dengan mengikuti pola irama iringan musik sehingga dapat menyentuh perasaan siswa. Siswa juga membentuk lingkaran sehingga semua siswa dapat dikontrol guru saat siswa berisik ataupun siswa yang pasif dapat segera diberikan bimbingan. Kemampuan menulis puisi siswa pada siklus III mengalami peningkatan terbukti pada tabel 10 yaitu kategorisasi hasil belajar.

Tabel 9 Observasi pengelolaan pembelajaran guru dengan metode sugestopedia siklus III

\begin{tabular}{|c|c|c|c|c|c|}
\hline \multirow{2}{*}{ No } & \multirow{2}{*}{ Aspek } & \multicolumn{4}{|c|}{ Skor } \\
\hline & & 1 & 2 & 3 & 4 \\
\hline 1 & $\begin{array}{l}\text { Memulai pembelajaran dengan memberi motivasi pada } \\
\text { siswa }\end{array}$ & & & & $\sqrt{ }$ \\
\hline 2 & Menguasai dan menyajikan konsep materi pembelajaran & & & & $\sqrt{ }$ \\
\hline 3 & Mengarahkan perhatian siswa dan kontak mata & & & & $\sqrt{ }$ \\
\hline
\end{tabular}


$4 \quad$ Antusiasme, penamapilan menarik

5 Mengaplikasikan setiap langkah-langkah metode sugestopedia dalam kegiatan belajar mengajar

6 Keterampilan penggunaan media dalam penerapan metode sugestopedia

7 Memberikan kesempatan kepada siswa untuk bertanya

8 Memberikan latihan

9 Membimbing siswa yang kurang paham materi

Dari tabel 10 diperoleh data tentang kemampuan menulis puisi siswa pada siklus III. Jumlah rata-rata hitung yang diperoleh siswa dari keseluruhan aspek yang dinilai adalah 72. Hasil ini menunjukkan sebagian besar siswa mencapai KKM. Kemampuan awal siswa dalam menulis puisi pada siklus III dapat digambarkan pada grafik seperti pada Gambar 6.

Tabel 10 Kategori kemampuan menulis puisi siklus III

\begin{tabular}{|c|c|c|c|c|c|}
\hline No. & Rentang Nilai & Jumlah & $\%$ & Kategori & Rata-rata \\
\hline 1 & $80-100$ & 9 & 30 & Sangat baik & 2256,25 \\
\hline 2 & $66-79$ & 15 & 50 & Baik & 30 \\
\hline 3 & $56-65$ & 5 & 16,66667 & Cukup & \\
\hline 4 & $40-55$ & 1 & 3,333333 & Kurang & \\
\hline 5 & $30-39$ & 0 & 0 & Sangat kurang & \\
\hline
\end{tabular}

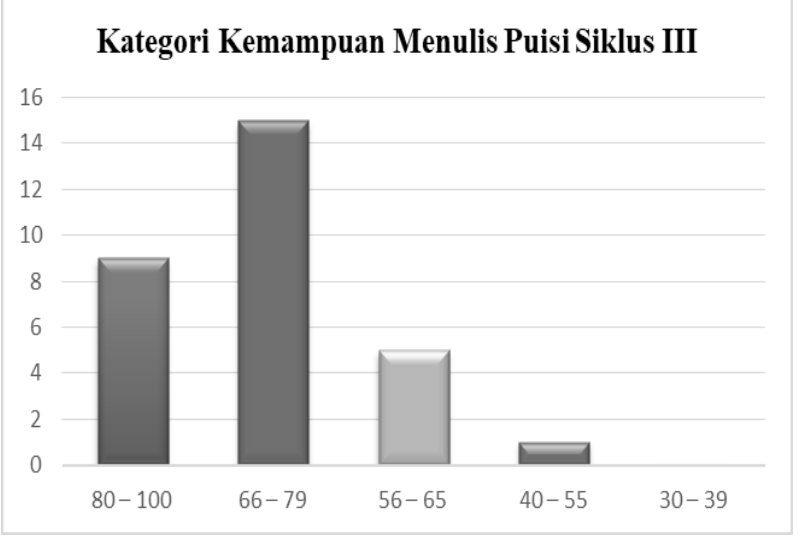

Gambar 6 Kategorisasi kemampuan menulis puisi siklus III

\section{Pembahasan}

Dalam pembahasan ini akan membahas mengenai pembelajaran menulis puisi dengan menerapkan metode sugestopedia.

\section{Pembelajaran Menulis Puisi dengan Metode Sugestopedia}

Penerapan metode sugestopedia dalam pembelajaran menulis puisi di kelas V SDN
Muktiwari 02 Kecamatan Cibitung Kabupaten Bekasi membuktikan bahwa penerapan metode sugestopedia dapat meningkatkan kualitas pembelajaran manulis puisi yaitu peningkatan pencapaian hasil belajar siswa dan dapat menciptakan suasana nyaman dan kondusif selama pembelajaran berlangsung.

Dengan menerapkan metode sugestopedia dalam pembelajaran siswa terlihat lebih tertarik dan percaya diri dengan nama panggilan siswa yang beisi kata-kata motivasi seperti pemberani, si cerdas, si pitar, si tangkas, dan lain-lain sehingga proses belajar lebih efektif dan menarik. Melalui teks narasi dan musik, siswa tidak mengalami kesulitan dalam mengimajinasikan atau membayangkan tema puisi karena emosi siswa mudah larut dalam alunan musik dan narasi yang dibawakan secara dramatik oleh guru.. 


\section{Hasil Belajar Siswa dengan Penerapan Metode Sugestopedia}

Hasil belajar siswa pada pembelajaran bahasa Indonesia khususnya menulis puisi dengan menerapkan metode sugestopedia terbukti sangat efektif dalam menunjang keberhasilan siswa di sekolah. Dari sebelum tindakan pertama hingga tindakan ke tiga diperoleh nilai rata-rata menunjukan hasil belajar siswa meningkat.

Dengan menerapkan metode sugestopedia dalam pembelajaran menulis puisi dapat merangsang daya imajinasi siswa dan memudahkan siswa dalam menemukan diksi, imaji dan bahasa fuguratif yang sesuai dengan tema narasi sehingga bahasa puisi yang dibuat lebih bervariatif.

\section{Hasil Nilai Tes Siswa}

Untuk melihat hasil tes siswa mulai dari pra siklus sampai dengan siklus ketiga dapat dilihat dari Tabel 11.

Tabel 11 Rekapitulasi nilai rata-rata tes per siklus

\begin{tabular}{lc}
\hline \multicolumn{1}{c}{ Siklus } & Nilai rata-rata \\
\hline Pra Siklus & 51.88 \\
Siklus I & 62.5 \\
Siklus II & 68.96 \\
Siklus III & 75.2 \\
\hline
\end{tabular}

Berdasarkan data pada Tabel 11 ditunjukkan nilai rata-rata tes siswa mulai dari pra siklus sampai dengan siklus ke III mengalami peningkatan. Nilai rata-rata pra siklus sebesar 51,88, siklus I sebesar 62,5, siklus II sebesar 68,96, dan siklus III sebesar 75,2 . Ini membuktikan bahwa dengan menerapkan metode sugestopedia telah menghasilkan peningkatan kualitas guru dalam proses pembelajaran menulis puisi, dan hasil kemampuan menulis puisi siswa di sekolah dasar.

\section{KESIMPULAN DAN IMPLIKASI}

\section{Kesimpulan}

Berdasarkan hasil penelitian penerapan metode sugestopedian dalam meningkatkan kemampuan menulis puisi siswa yang dilaksanakan pada kelas V SDN Muktiwari 02 Kecamatan Cibitung Kabupaten Bekasi dapat disimpulkan sebagai berikut:

1) Sebelum menerapkan metode sugestopedia dalam pembelajaran menulis puisi di SDN Muktiwari 02 Kecamatan Cibitung Kabupaten Bekasi hasil belajar siswa yang diperoleh sangat rendah. Ini didasarkan kepada hasil evaluasi pra siklus dengan rata-rata kelas hanya sebesar 51,88. Siswa kurang mendapat stimulus yang baik selama pembelajaran menulis puisi. Guru masih menerapkan metode pembelajaran ceramah yang berpusat pada guru sehingga siswa tidak aktif dan terkesan membosankan.

2) Selama proses pembelajaran dengan menerapkan metode sugestopedia lebih menunjukkan suasana pembelajaran yang kondusif. Ini terlihat pada aktivitas siswa selama pembelajaran dengan diiringi musik terlihat rileks, tidak tegang dan luwes dalam menyimak metri dan melakukan tanya jawab dengan guru. Siswa juga terlihart konsentrasi dan bersungguh-sungguh dalam menghayati dan mengimajinasikan sugesti dan narasi yang dibuat oleh guru.

3) Setelah menerapkan metode sugestopedia, kemampuan menulis puisi siswa telah menunjukkan peningkatan dalam pembelajaran dengan hasil ratarata tes mulai dari siklus I sebesar 62,50 , siklus II sebesar 68,96, dan siklus III sebesar 75,20 dikarenakan guru 
menggunakan metode sugestopedia sehingga proses pembelajaran terlaksana dengan baik dan peningkatan hasil observasi pengelolaan pembelajaran guru dengan metode sugestopedia pada siklus I sebesar 2,77, pada siklus II sebesar 3,3 dan pada siklus III sebesar 3,78 hal ini menunjukkan bahwa pengelolaan pembelajaran yang dilakukan oleh guru dengan menggunakan metode sugestopedia meningkat.

\section{Implikasi}

Untuk keberhasilan dalam proses pembelajaran bahasa Indonesia khususnya memulis puisi terutama di Sekolah Dasar, maka penelitian ini diimlikasikan kepada:

1) Pendidik, dalam proses pembelajaran menulis puisi di Sekolah dasar guru seyogyanya lebih peka terhadap kondisi siswa. Terkadang siswa kelelahan dengan aktifitas pembelajaran sebelumnya. Sehingga dengan kepekaan guru, dan penerapan metode yang menyenangkan seperti sugestopedia dapat meningkatkan efektivitas pembelajaran.

2) Peneliti lainnya, meskipun penerapan metode sugestopedia dalam penelitian menunjukkan adanya peningkatan proses dan hasil pembelajaran, namun perlu kiranya rekan-rekan pendidik untuk mengadakan penelitian lebih lanjut, yaitu dengan cara mengujicobakan menerapkan metode sugestopedia dengan pokok bahasan atau kelas yang berbeda untuk memperoleh peningkatan keberhasilan dalam pembelajaran.

3) Lembaga atau instansi terkait khususnya lembaga sekolah diharapkan lebih memperhatikan para pendidik, memberikan pelatihan, pembinaan, agar peningkatan profesionalisme berjalan dengan yang diharapkan.

\section{DAFTAR PUSTAKA}

Dardjowidjojo, S. (2002). Lima Pendekatan Mutakhir dalam Pengajaran Bahasa. Jakarta: Pelita SInar Harapan.

Depdiknas. (2006). Kurikulum Tingkat Satuan Pendidkan (KTSP). Jakarta: Depdiknas.

Pradopo, R. D. (2002). Pengkajian Puisi. Yogyakarta: Gadjah Mada Univeristy Press.

Richards, J. C., \& Rodgers, T. S. (1999). Approach and Methoids in Language Teaching. United Kingdom: Cambridge University Press.

Sadikin, M. (2010). Kumpulan Sastra Indonesia Pantun, Puisi, Majas, Pribahasa, Kata Mutiara. Jakarta: Gudang Ilmu.

Sudjana, N. (2005). Tuntunan Penyusunan Karya Ilmiah (Makalah-Skripsi-TesisDisertasi). Bandung: Sinar Baru Algensindo.

Tarigan, H. G. (2008). Menulis sebagai Suatu Keterampilan Berbahasa. Bandung: Angkasa.

Waluyo, H. J. (2007). Teori dan Apresiasi Puisi. Jakarta: Erlangga. 